\title{
AGRICULTURAL LABOUR AND RURAL LABOUR RELATIONS IN WEST BENGAL
}

\author{
Dr. Kakali Barua \\ Lady Shri Ram College for Women, University of Delhi \\ DOI: 10.46609/IJSSER.2021.v06i07.006 URL: https://doi.org/10.46609/IJSSER.2021.v06i07.006
}

\begin{abstract}
This paper explores rural labour relations in West Bengal. In an attempt to understand rural labour relations, we focus on credit in the labour market and to what extent agricultural labourers who take credit (in the form of wage advance) from their employers have the freedom to work for different employers. Our results show that many who took wage advancement against future commitment of labour was associated with weak bargaining power, working on priority basis, involving longer working hours and underpayment of work. Though, no bondage due to debts was reported from the villages, agricultural labourers had the freedom to sell his/ her labour power freely in the market. But given large scale poverty and unemployment, formal freedom of free sale of labour power to a large section of agricultural labourers was still limited in rural Bengal.
\end{abstract}

Key Words: West Bengal; agricultural labour; rural labour relations; rural labour market; indebtedness.

\section{Introduction}

Agriculture is important in India's political economy, as a large section of rural population is directly depended on it for its livelihood. One of the important agrarian themes that are of interest is the economic conditions of agricultural labourers. There are many parameters to analyze the economic conditions of agricultural labourers, important among them are wage and employment. Economic condition of agricultural labourers also depends upon the extent to which they can freely sell their labour in the labour market i.e. the kind of labour relations that prevails in the rural economy. To analyze the rural labour relations, we look at the credit market and the impact of this on the conditions of employment of agricultural labourers. 


\section{International Journal of Social Science and Economic Research}

ISSN: $2455-8834$

Volume:06, Issue:07 "July 2021"

As, we all know, economic condition of agricultural labourers ${ }^{1}$ depend primarily upon the real earnings, which are affected by availability of employment, agricultural wages and price of wage goods consumed by members of the household. These three factors, together with the ability of the labour force to sell labour power freely in the market determine the economic condition of agricultural labourers, but no study on the economic condition of agricultural labourers is complete until we look at the aspect of the employer employee relation.

The current paper aims to look at rural labour relations in West Bengal; we focus on the interlinkage of credit in particular, and wage advancement with other contracts in the credit and labour market. Also, analyze to what extent agricultural labourers who have take credit in the form of wage advancement from their employers have the freedom to work for different employers to what extent do such relationships affect the employment conditions and bargaining power of agricultural labourers. This paper is based on fieldwork results done the two districts of West Bengal in India ${ }^{2}$.

\section{CHARACTERISTICS OF THE LABOUR MARKET IN THE SURVEYED VILLAGES}

In the surveyed villages, we observed that a large section of agricultural labourers were daily casual labourers, attached labourers were almost non-existent in the villages. Moreover, wage employment opportunities was very disappointing, growth rate of employment and wages in the farm sector was declining in the post reform period ${ }^{3}$ both for men and women. Our field survey data showed that unemployment last for five to six months for men and even more for women workforce. Also market wage rate ${ }^{4}$ was below the minimum wages declared by the government, and at times when agricultural activity is not in its peak, agricultural labourers have to settle at an abysmal low wage rate. Employment diversification if any was not able to reduce rural/ agricultural labour force dependence on farm sector, the field survey data also show that the influence of rural employment diversification in influencing the pattern of farm wages especially

\footnotetext{
1 Agricultural labourers constitute both landless and semi landless households. Landless households are defined as those owning either no land or land less than 0.005 acres, while semi- landless are defined as those who own land between (0.005-0.5) acres of land.

${ }^{2}$ For methodology please see Appendix 2, section A.

${ }^{3}$ Liberalization started in 1990s in India.

${ }^{4}$ The prevailing wage rate for male agricultural labourers in Nadia was 40 rupees (All rupees in Indian rupees and the exchange rate is $1 \$=46.7$ rupees and $1 £=68.4$ rupees) and 35 rupees for female agricultural labourers. On the other hand in Jalpaiguri, the wage rate for male agricultural labourers was 60 rupees while it was 40 rupees for female agricultural labourers. The minimum wage fixed by the government of West Bengal was 74.33 Indian rupees without meals and 71.3 Indian rupees with meals as on 2007-08.
} 


\section{International Journal of Social Science and Economic Research}

ISSN: $2455-8834$

Volume:06, Issue:07 "July 2021"

in Nadia district has been very negligible. According to the $61^{\text {st }}$ round of National sample Survey Organization of India, 65 percent of the agricultural labour households in West Bengal were indebted. Primary survey results showed that a large section of agricultural labour households in the surveyed area were below the poverty line ${ }^{5}$. Current income from all sources was not being enough to sustain the livelihood of agricultural labourers, which means that a large section of agricultural labourers have to resort to borrowing to meet their daily consumption needs. Given the fact that agricultural labourers access to institutional credit is limited, they have to resort to non-institutional source of finance to meet their consumption needs.

\section{Characteristic of the Credit Market}

As, it is well known that greater part of rural population do have any land and or have too little to offer as mortgage. Thus, explaining as to why a large section of rural population remains outside the formal credit market and have to largely depend upon non-institutional source of credit like moneylenders, landlords, employers, friends and relatives. This was evident in our sample area, as borrowers in our sample villages relied mostly on informal credit market, which was mostly dominated by employers /landlords, rich farmers and traders. Traders who usually run small business in the villages are not seen as a separate class; the big landlords or rich farmers run these retail shops where items for daily consumption are available or run shops where organic fertilizer, seeds or pesticide is available. They give interest free loan to poor households in the form of consumption items or inputs for crops, the only interest of shopkeepers in giving such loan is that this is an important means of maintaining a scale of their business which otherwise would not be possible. Hence, it is often seen that the landlord /employer is also the trader and the apart from moneylender the principal lender in the rural credit market.

\section{Purpose of borrowing and source of credit}

In both Nadia and Jalpaiguri, borrowing for consumption purposes was the most important form of borrowing by landless agricultural labour household, followed by borrowing for medical and household ceremonies. For, other than landless agricultural labour households, borrowing for production purpose constituted the most important form of borrowing followed by borrowing for consumption purpose. Finally, for agricultural labourers who operate land (owned and leased in), borrowing was mainly for production purpose, followed by borrowing for consumption purpose, borrowing for marriage ceremonies and medical purposes.

Institutional source of borrowing appeared to be an insignificant source of borrowing for agricultural labour households as they cannot give any collateral in exchange for loans.

\footnotetext{
${ }^{5}$ Please refer to appendix 2, section B for a note on poverty in the surveyed area.
} 


\section{International Journal of Social Science and Economic Research}

ISSN: $2455-8834$

Volume:06, Issue:07 "July 2021"

Agricultural labourers both landless and landed agricultural labourers (agricultural labourers who own land or lease in land) borrow mostly from non-institutional source. As a percentage of total debt, borrowing was mostly from moneylenders and landlords across all the surveyed villages in Nadia and Jalpaiguri. Shopkeepers (who give consumption items on credit or gives inputs like fertilizer and seeds on credit) constitute the other main source of lenders for agricultural labourers. However, in Boron Beria village of Nadia district, borrowing from NGO constitutes an important part, this is due to the prevalence of NGO (non- government organization) in that village.

As our survey results, show that a large section of agricultural labourers were below the poverty line $^{6}$, their current income were not only insufficient to meet their production needs, but also insufficient to meet their current consumption. In many such cases loan/ credit taken by agricultural labourers for consumption purposes, has led to interlinkage with other contracts like labour. This sort of dependence often leads to unequal bargaining power by the labourers and often leads to appropriation of surplus in the form of unpaid labour services by the landlord and employer.

\section{Wage Advance and Interlinked Modes of Exploitation}

It is often seen that agricultural labourers during lean season take wage advance mostly in cash from their employers with the commitment (mostly) that during peak season they will work for the concerned employer. An important feature of wage advance is the link between the consumption credit and tying up of labour services. From the employer's point of view, they may be willing to give such wage advance to agricultural labourers as boro rice ( summer rice) are largely of short duration and agricultural operations have to be performed in a short time to avoid any loss in yields, jute is also an important crop which requires specialized and timely labour. To avoid any uncertainty in the ready availability of labour and save time in recruitment in the growing or harvesting season, employers may provide credit against future commitment of labour services. From the labourers point of view in absence of regular employment in farm and non-farm sector such wage advancement is necessary to sustain them during lean season. In this process of wage advancement, it is often argued that some extra economic coercion is involved which robs the labourer his freedom to work for according to his own choice. This process of wage advancement also forces the labourers into perpetual indebtness (discussed later).

\section{Wage Advancement in Nadia (Advanced) District}

\footnotetext{
${ }^{6}$ Please refer appendix 2, section B for a note on poverty in the surveyed area.
} 
Table 1, Appendix 1, shows the percentage of agricultural labourers taking wage advance against future commitment of labour.

- For landless labour households: In Nadia, 69 percent of landless agricultural labourers have taken loan against future commitment of labour.

- For other than landless labour households: On the other hand those agricultural labour households who either own land or lease-in land, 52.6 percent of them took wage advance..

- For all agricultural labourers : Taking all the agricultural labourers together i.e. landless and those who own land or lease in- land, 61.3 percent of them took wage advancement against future commitment of labour in Nadia district. Our data show that wage advancement against future commitment of labour goes down with increase in land size, as working in own and other's farm simultaneously becomes difficult.

\section{Wage Advancement in Jalpaiguri (Backward) District}

- Landless labour households: In Jalpaiguri (please refer table 1, Appendix 1) only 13 percent of landless agricultural labourers have taken wage advance against future commitment of labour. Contrary to Nadia, in Jalpaiguri proportion taking wage advance against future commitment of labour is lower among landless agricultural labourers. Others who have not taken wage advance is either because they have land owned or leased in , taking wage advance would mean that they will have work to the respective employer. The rest, mostly landless labourers did not take wage advance as they did not get it. On the whole, proportion of agricultural labourers taking wage advancement against future commitment of labour is lower in the backward district than in the advanced district.

- Other than landless labour households: On the other hand those agricultural labour households who either own land or lease-in land, 28.2 percent of such agricultural labourers took wage advancement against future commitment of labour.

- All agricultural labour households: Taking all the agricultural labourers together i.e. landless and those who own land or lease in- land, 19.4 percent of agricultural labourers took wage advancement against future commitment of labour.

\section{Some Observation on Wage Advancement}

Wage advancement against future commitment of labour service forms the dominant contract and which was higher in the advanced district. We observed the trend where credit contract 


\section{International Journal of Social Science and Economic Research}

ISSN: $2455-8834$

Volume:06, Issue:07 "July 2021"

interlinked with labour service forms the dominant contract and which was higher in the advanced district, this was due to the intensity of agricultural activity in that area which often required employers (landlords, moneylenders) to tie labour for peak season. In the advanced area, we observe widespread cultivation of boro rice, which is a high yielding variety, and which requires time bound labour to avoid any loss, jute, which is a labour intensive crop and requires specialized labour especially after its harvest during jute retting ${ }^{7}$. On the other hand in Jalpaiguri , agricultural activity was such that employers( landlords, moneylenders) did not require the need to tie labour for peak season activity this was due reason already discussed above. In Nadia most of the wage advancement against future commitment of labour which took place was to tie labour for the peak season. Out of the 20 cultivator/employer respondent 95 percent told that they gave wage advance to tie labour during peak season, as harvesting/sowing of boro requires timely labour to avoid any loss in yield. But from the labourer's point of view, they would want to avoid taking any such advances as it reduces their bargaining power substantially.

On the other hand in Jalpaiguri (backward economy), such wage advance takes place not to tie labour during peak season, labour supply is not a problem in this area. Given the cropping pattern, only a few agricultural managed to get wage advance. Agricultural labourers in absence of any other source of credit, goes to the employer for such wage advancement in return of committed labour during peak season. Where they have to work for longer than normal working hours at the market wage rate or have to work at lower wage rate than the market wage.

In the next section we see whether such wage advanced is due to any extra economic coercion and to what extent such arrangements are mutually beneficial to both the employer and employee.

\section{Modes of Wage Advance Repayment in Terms of Labour in the Surveyed Villages}

Table 2, Appendix 1, gives details of associated contracts that come with wage advancement; wage advances against future commitment of labour are usually interest free. Wage advancement is associated not only with future commitment of labour, given the extent of vulnerability of agricultural labour households it also means underpayment of work for majority of agricultural labourers, working on priority basis and working longer hours. While interviewing the agricultural labourers, they told that taking wage advance reduces their bargaining power substantially to demand for higher wages during peak season. If for e.g. during peak season market wage rate rises by another 20-30 rupees, then it becomes difficult for agricultural

\footnotetext{
${ }^{7}$ Jute retting: Cleaning and washing of raw jute.
} 


\section{International Journal of Social Science and Economic Research}

ISSN: $2455-8834$

Volume:06, Issue:07 "July 2021"

labourers to bargain for higher wages, they usually have to settle for the market wage rate or sometimes even less. Repayment of wage advance is usually made through deductions from wage. Such wage advance usually does not exceed rupees 300-400, hence if agricultural labour A has taken wage advance of 100 and if he works for 10 days for the employer then rupees 10 is deducted every day from his wage.

In all the surveyed villages of Nadia, on an average 83.7 percent of landless agricultural labourers have said that wage advance involves underpayment of work (refer table 2, appendix 1). The proportion of agricultural labourers who have taken wage advance and who report underpayment of work declines for those who operate land (whether owned or leased in). Our result show that in Nadia district, 65.7 percent of them reported that wage advancement involves underpayment of work.

The results from Jalpaiguri, also confirms that 85.7 percent of landless agricultural labourers and 83.2 percent of those who are not landless, report wage advance accompanying under payment of work .

The other important aspect with respect to wage advancement is that, once wage advance is taken then it becomes mandatory for the labour to work on priority basis for the respective employer and even if he gets higher wage rate somewhere else he cannot take it up due to his commitment to the employer from whom he has taken wage advance. Somewhere, agricultural labourers also do not breach the 'unofficial' contract, as many argued that they cannot afford to do so, as in the next lean season they have to fall back on to their respective employer for grains and cash advancement to sail through the rough times, if refuse to work for that employer they have to starve during the period when they are unemployed.

The findings from our field survey show that 91.8 percent of landless agricultural labourers in Nadia and all landless agricultural labourers in Jalpaiguri reported that if wage advanced is taken then they had to work on priority basis. 71.4 percent of agricultural labourers (who operated land whether owned or leased in) in Nadia and all agricultural labourers who had taken wage advancement in Jalpaiguri worked on priority basis. The proportion of agricultural labourers who report to have worked on priority basis was higher among landless agricultural labourers than the ones who operated land (whether leased-in or owned).

Finally, on the aspect of rural labour relations exploring whether wage advancement is associated with normal working hours, the findings show that 73.5 of percent landless agricultural labourers in Nadia (average of the two villages) and 85.7 percent in Jalapiguri (average of the two villages) have reported that wage advanced did not involve normal working conditions, which usually meant working longer for hours (usually more than eight hours). Agricultural labourers have 


\section{International Journal of Social Science and Economic Research}

ISSN: $2455-8834$

Volume:06, Issue:07 "July 2021"

argued that taking wage advancement usually involves longer working hours, which is usually not accompanied by higher wages. On the other hand, 71.4 percent of agricultural labourers in Nadia and 58.3 percent in Jalapiguri who cultivated land reported that wage advance did not involve normal working conditions.

Thus, we see that wage advancement is associated with weak bargaining power, working on priority basis, involving longer working hours and underpayment of work, this is more pronounced in the agriculturally more dynamic area. Such labour tying is an important source of labour mobilization in Nadia than in Jalpaiguri. Employers across all the village in Nadia district had to say that supply of labour falls short than the demand during peak season. Bringing labourers from outside the village or district is costly to them as they have to provide accomodation and food to the inmigrant labourers. Except the big farmers others cannot afford to hire immigrant labourers, hence it becomes important that agricultural labourers are tied for peak season. On the other hand, in Jalpaiguri labour tying does not seem to be the reason for wage advancement, wage advancement was more for social control of labourers.

Mass unemployment in farm sector and uncertainty in the non farm sector forces agricultural labourers to take wage advancement from employers at contacts which are not favourable to agricultural labourers. Agricultural labourers ruled out any extra economic coercion in such interlinkages, on the contrary it is agricultural labourers desperate economic condition which lands them up in such credit interlinkages. Given an option they would not willingly want to enter into such interlinked contracts. Such form of interlinkages may be of some advantage to the employer, but from the labourers point of view any advantage in such interlinked contracts is highly skeptical.

\section{Freedom of choice to work}

To the question of whether such interlinked contract leads to long term bondage, the answer may be slightly complicated as most of the contracts between the lender and borrower are informal. Majority of agricultural labourers have the freedom to accept or reject the conditions of employment and wages offered by the employer. But, as our analysis show that economic conditions of agricultural labourers is very disappointing, they have to resort to borrowing from various sources to meet their consumption needs, which in turn leads to interlinked contacts where repayment is done through labour. Such interlinked contracts also lead to longer duration of work, underpayment of work and under pricing of output and unequal bargaining power. This implies that for a large section of agricultural labourer's formal freedom or his/ her ability to sell labour freely in the market may be very limited in rural West Bengal.

\section{Characteristic of borrowers who take wage advancement}




\section{International Journal of Social Science and Economic Research}

ISSN: $2455-8834$

Volume:06, Issue:07 "July 2021"

Our discussions in the previous section show that the income of the labour households is not enough to meet their current consumption; this leads to borrowings from various sources. In absence of any non- labour assets to offer as collaterals they may be forced to take wage advancement against future commitment of labour. In this section, we will look into the various factors which determine the interlinked contract (terms the wage advancement against future commitment of labour).

Dependent Variable: If wage advancement is taken against future commitment of labour. 1 if wage advancement is taken against future commitment of labour, 0 if otherwise.

\section{Independent Variables:}

Area owned or leased in (lanown): If the labour household owns or leases in some land then their own/leased-in land will need timely labour input during agricultural activity. Taking wage advancement against future commitment of labour will mean adverse terms of condition as they will be bound to work for others even when they are needed in their own/leased-in land. Hence, this variable should be negatively related to wage advancement against future commitment of labour.

$1=$ if land is owned/leased-in

$0=$ otherwise .

Caste (SS): As schedule caste and tribes households have greater disadvantage as far as access to various economic opportunities are concerned. In such situation they will have to raise credit on adverse terms and conditions. This variable is expected to be positively correlated with linkage.

$1=$ if Schedule caste/ tribe household.

$0=$ otherwise .

Education (edn): Education increases the probability of getting jobs outside the farm sector. This will help in increasing the total income of the household. This variable is expected to be negatively correlated with interlinked contracts.

$1=$ if literate

$0=$ otherwise

Income from outside the farm sector (percapin): Given the fact that an employment opportunity in the farm sector is limited, a household try to supplement its income by working in the non farm sector. Higher is the per capita income from outside the farm income lesser will be the need 
to take wage advancement against future commitment of labour at predetermined wage rates in the farm sector. Therefore, this variable is expected to be negatively related with interlinked contract.

Proportion of Male Workers to Total Workers in the Households (malwork): The more the number of male workers to total workers in the households, the higher the probability of getting wage advancement against future commitment of labour. This is essentially due to the fact that the landlord will assured of getting the supply of labour during peak agricultural activity. Thus this variable will be positively correlated with interlinked contact.

Worker Dependent Ratio (wrkdep): The higher the worker dependent ratio, higher will be the earning capacity of the household and lesser the need to take wage advancement with labour tying. This variable will be negatively correlated with labour tying. Worker dependent ratio is calculated as $=(\text { Total Worker } / \text { Total Family Members })^{*} 100$

\section{Methodology}

We use the cross section analysis by taking all the variables both dependent and independent variables in the $\log$ form. :

$\operatorname{In} Y=a+b_{i} \ln X_{i}+u$

Where $\mathrm{Y}=$ dependent variable.

$\mathrm{a}=$ constant term .

$\mathrm{X}_{\mathrm{i}^{\prime} \mathrm{s}}$ are the explanatory variables.

Where $\mathrm{i}=1,2,3 \ldots . .231$ for 231 households in four villages of Nadia and Jalpaiguri district for the year 2006-07

$b_{i}$ are the coefficients which are estimated and $u$ is the error term. 


\section{The Result:}

\section{Dependent variable}

1 if wage advancement is taken against labour tying

0 otherwise

\begin{tabular}{|l|l|l|l|l|l|l|}
\hline loaadl & Coef. & $\begin{array}{l}\text { Std. } \\
\text { Err. }\end{array}$ & $\mathbf{Z}$ & $\mathbf{P}>\mathbf{z}$ & $\begin{array}{l}{[\mathbf{9 5 \%}} \\
\text { Conf. }\end{array}$ & Interval] \\
\hline wrkdep & -0.7604 & 0.2767 & -2.7500 & $0.0060^{* *}$ & -1.3027 & -0.2181 \\
\hline malwork & 0.1598 & 0.1425 & 1.1200 & 0.2620 & -0.1195 & 0.4390 \\
\hline ss & 0.1332 & 0.2978 & 0.4500 & 0.6550 & -0.4505 & 0.7169 \\
\hline percapin & 0.4063 & 0.1280 & 3.1800 & $0.0010^{* *}$ & 0.1555 & 0.6571 \\
\hline edn & -0.0274 & 0.3160 & -0.0900 & 0.9310 & -0.6467 & 0.5919 \\
\hline landown & -0.2469 & 0.3080 & -0.8000 & 0.4230 & -0.8505 & 0.3566 \\
\hline
\end{tabular}

*significant at $10 \%$ level.

** significant at $5 \%$ level.

$* * *$ significant at $1 \%$ level.

\section{Discussion of the result}

The results of the maximum likelihood estimates of the binary logit model are shown in table A. All the variables have the expected sign, except per capita non farm income, which do not show the expected sign. The only variable which significantly affects the labour household's decision of taking wage advancement against future commitment of labour is worker dependent ratio. The higher the worker dependent ratio, higher the earning capacity of the household and lesser the need to take wage advancement with labour tying at adverse conditions.

Other factors such as social status, education and land owned/leased-in do not significantly affect the household's decision in labour tying.

Thus, labour households which have higher worker dependent ration will have higher earning capacity of the households and lesser need to take wage advancement with labour tying.

\section{PRESENT ECONOMIC SITUATION IN BENGAL AND ITS IMPACT ON RURAL LABOUR RELATIONS}

Agriculture did fairly well in West Bengal up to the mid-1990s in terms of production. After that, the cost of production went up because of withdrawal of subsidies but the prices of agricultural products did not go up. These are indications, that for small and marginal farmers cultivation was no longer viable in West Bengal. This implies that now more and more rural population will 


\section{International Journal of Social Science and Economic Research}

ISSN: $2455-8834$

Volume:06, Issue:07 "July 2021"

have to depend on earnings by working either on other person's farm or by working in nonfarm sector either to supplement their current income or depend entirely on it for living.

Land reforms introduced by the Left Front Government (LFG), after its initial success failed to keep up with the required momentum. The two important programme introduced by the LFG in 1977 was land redistribution ${ }^{8}$ and registration of bargadars ${ }^{9}$. According to the official record of the Government of West Bengal ${ }^{10}$, an average of one third landless and land poor have been covered by land redistribution. The land which was vested with the government was usually one which was not fit for cultivation or land which was very less productive. This combined with rising cost of cultivation made things even more difficult for the rural households, as it became difficult to cultivate the already less productive land because of higher cost of cultivation, reduced access to institutional credit and lower prices making cultivation a less viable option for subsistence.

Human Development Report on West Bengal shows that by 2001, 14.37 of the bargadars (registered sharecroppers) have been evicted and 13.23 of the pattadars (registered owners) have lost possession of land. Thus, the government's initiative to protect the interest of the landless and landed rural households through the land reform measures was inadequate.

On the other hand, the ownership pattern in rural Bengal saw a secular decline and the total disappearance of large landlord over years which has not taken place anywhere in India. This has led to the emergence of the middle category as the new ruling class in rural West Bengal. Who ruled the panchayats in rural Bengal and they together works against the interest of rural/agricultural labourer's, as any rise in the wage rate would reduce their profits.

National rural employment guarantee act (NREGA) ${ }^{11}$ which was implemented failed to provide adequate employment to the rural/ agricultural labour force. Labourer's got anything between 520 days of work under rural labour employment programme.

Thus, on one hand the improper implementation of land reform measure, combined with rising cost of cultivation, made the economic condition of rural poor worse pushing them away from

\footnotetext{
8 Redistribution of Land: It involves redistribution of ownership of excess land acquired from rich landlords through implementation of land ceilings. Land above the ceiling surplus will be redistributed among the land poor and the land-less.

${ }^{9}$ Operation Barga is nothing but a massive drive to register the names of the sharecroppers with the collaboration of the groups of beneficiaries with the active assistance of the peasant organization

${ }^{10}$ Economic Review, Various issues, Government of West Bengal

${ }^{11}$ NREGA: National Rural Employment Guarantee Act which was instituted by the government of India in 2005, ensuring 100 days employment to rural workforce.
} 


\section{International Journal of Social Science and Economic Research}

ISSN: $2455-8834$

Volume:06, Issue:07 "July 2021"

the means of production. This led to their reliance on earnings by working either as agricultural labourer's or as non- farm worker, but given that non-farm employment opportunities especially in the advanced district is scarce and seasonal, the reliance on farm employment is increasing over time. The scenario in the farm sector is far from good. The employment trend ( please refer table 6, appendix 3) show that both by UPSS ${ }^{12}$ and $\operatorname{CDS}^{13}$ measure, total rural employment in West Bengal and in all India declined during 1993-94/2004-05 as compared to the previous period 1983/1993-94 ${ }^{14}$. Growth rate of rural employment in the primary sector declined both in Bengal and in all India in the post reform period (1993/94-2004/05). Rural unemployment rates (please refer table 8, appendix 3) have increased in the post reform period by both usual and current daily status for rural males and females at the all India level. Incidence of casualisation has been increasing both for male and female workers in rural India and in rural Bengal. Table 8; show the rural unemployment rate in West Bengal and in all India. By the usual status measure rural unemployment rates increased in the post reform [after (1993/94) period] for rural males and females at all India level. A clearer picture emerges from the current daily status, where at all India level rural unemployment rates show a continuous rise in the post reform period between 1993/94 and 2004-05 both for males and females. Thus unemployment rates have continuously been increasing in the post 1993/94 period by both usual and current daily status for males and females.

Primary survey also shows that massive unemployment exists in rural Bengal, the results on per capita total employment availability in the surveyed village's show that male casual labourers got 182 days of employment and women got 148 days of employment in Nadia. In Jalpaiguri, this figure was 178 days for men and 109 days for women.

The post reform period also witnessed a falling growth rates in agricultural output, with falling output in the agricultural sector the labour demand has been declining in rural Bengal in the post reform period.

\footnotetext{
${ }^{12}$ According to usual status, the status of activity on which a person spent relatively longer time of the preceding 365 days from the date of survey is considered as the principal usual status activity of the person. Accordingly, a person is considered 'working or employed' if the person was engaged for a relatively longer time during the past year in any one or more work related activities(economic activities) including seeking or being available for work. The person is considered as 'seeking or available' for work or 'unemployed'. The specific activity category is determined on the basis of time spent criterion. i.e. the activity on which major time was spent being assigned as the usual status activity.

${ }^{13}$ In the current daily status (cds), the unit of classification was thus 'half day' in the cds. In assigning the activity status on a day, a person was considered working for the entire day if he had worked 4 hours or more during the day. If he had worked one hour or more but less than 4 hours, he was considered working( employed) for half day and seeking/available for work (unemployed) or not available for work (not in labour force) for the other half day depending on whether he was seeking /available for work or not.

${ }^{14}$ Please refer Appendix B
} 


\section{International Journal of Social Science and Economic Research}

ISSN: $2455-8834$

Volume:06, Issue:07 "July 2021"

The trends on wages (please refer table 7, appendix 3 ), from rural labour enquiry shows that growth rate of rural wages in the farm and non- farm sector for agricultural labour household and rural labour household declined in the post reform period as compared to the period of eighties in West Bengal. District wise results for West Bengal also show the same trend with almost all the districts registering a decline in the daily wage rate for male agricultural labourers. The ruling market wages (during 2006-07) was less than one dollar. Minimum wages fixed by the government of West Bengal was never implemented.

Falling wages and unemployment pushed many below poverty level. The primary survey confirmed that about 70 percent of the labour household surveyed in the villages of West Bengal was below the poverty line ${ }^{15}$.

The farm sector on the other hand is dominated by the middle peasants, immensely united among themselves with the help of panchayats work against the interest of agricultural workers. The absence of any kind of government support either in terms of implementation of minimum wages of effective implementation of NREGA or active unionization among agricultural labourer's, thus, making the economic position of agricultural labourer's even more vulnerable pushing many below the poverty line.

Thus, rural Bengal in the post reform period (1993/94-2004/05) has been characterized by a secular decline in rural employment, which has been accompanied by a decline in the wages of rural/agricultural labourers, increasing proportion of unemployment both for men and women, increased level of indebtedness, decline in the per capita consumption of cereals, together with the fact that daily casual wage rate in the farm sector was below the minimum wages declared by the Government of West Bengal.

Unemployment, poverty and falling annual income, falling consumption amounts to the fact that large section of rural population is unable to meet daily requirement whether that is for consumption or for cultivating their land. This means that large section of agricultural labour households have to resort to borrowing from informal sources in absence of formal source of lending, forcing many to take wage advancement during lean season. And as already discussed, wage advancement against future commitment of labour is associated with weak bargaining power, working on priority basis, involving longer working hours and underpayment of work.

\section{CONCLUDING REMARK'S}

\footnotetext{
${ }^{15}$ Please refer appendix B
} 


\section{International Journal of Social Science and Economic Research}

ISSN: $2455-8834$

Volume:06, Issue:07 "July 2021"

Our survey results show that labour markets in rural Bengal is characterized by firstly a disappearance of bonded labour, change in the pattern of employment, where the labour market is dominated by casual labourers, secondly, breakdown in the isolation of labour markets and finally very limited growth in nonfarm employment opportunities.

The rural economy in West Bengal, is characterized by falling growth rate of employment and rural wages in the farm sector, falling rural wages in the non farm sector, inequality in the ownership pattern of landholdings, falling output growth, increasing proportion of semi landless households and finally failure of the non-farm sector to absorb the growing proportion of workers in the rural Bengal. For a large section of the agricultural labour households employment in the village farm sector is the only viable option. Thus, large scale poverty, unemployment, indebtedness, illiteracy, dominance of the big/middle landholders inequality in land ownership, near absence of unionization to demand for higher wages especially in Naida, improper implementation of employment guarantee act (in Jalpaiguri) amounts to the fact that large sections of the agricultural labour households still have limited freedom for free sale of their labour power in rural labour market. Thus, agrarian change in the form of land reforms introduced by the state, NREGA, minimum wage laws failed to empower the poor landless and near landless households in West Bengal. The outcome as we have seen was widespread unemployment and poverty which in turn leads to freedom to work in limited sense and lower bargaining power.

We, conclude that though no formal bondage due to debt was reported from the surveyed villages, evident by a decline in the bonded labour. But, we observed that officially agricultural labourers had they formal freedom to accept and reject the employment contracts but large scale indebtedness still limits this formal freedom and agricultural labourers loses the freedom to exercise their choice in the labour market.

The economic condition of agricultural labourers can be improved, by proper implementation of the land reform programme, so that there is an equitable distribution of land, increasing public investments in the rural sector so that both farm and non-farm sector generates more employment opportunities, strengthening the public distribution system (PDS) so that agricultural labourers have easy and ready access to consumption Items, strengthening the Unions for agricultural labourers who would works in their interest and aim at empowering the rural poor.

\section{APPENDIX-1}


International Journal of Social Science and Economic Research

ISSN: $2455-8834$

Volume:06, Issue:07 "July 2021"

Table: 1

Wage Advancement against Future Commitment of Labour in Surveyed Villages

\begin{tabular}{|c|c|c|c|c|c|c|}
\hline & \multicolumn{2}{|c|}{$\begin{array}{c}\text { Landless labour } \\
\text { households }\end{array}$} & \multicolumn{2}{|c|}{$\begin{array}{l}\text { Other than landless } \\
\text { labour households }\end{array}$} & \multicolumn{2}{|c|}{$\begin{array}{c}\text { All agricultural } \\
\text { labour households }\end{array}$} \\
\hline & $\begin{array}{l}\text { All villages } \\
\text { in Nadia }\end{array}$ & $\begin{array}{l}\text { All villages } \\
\text { in } \\
\text { Jalpaiguri }\end{array}$ & $\begin{array}{l}\text { All villages } \\
\text { in Nadia }\end{array}$ & $\begin{array}{l}\text { All } \\
\text { villages in } \\
\text { Jalpaiguri }\end{array}$ & $\begin{array}{l}\text { All } \\
\text { villages } \\
\text { in Nadia }\end{array}$ & $\begin{array}{l}\text { All } \\
\text { villages in } \\
\text { Jalpaiguri }\end{array}$ \\
\hline Yes & $49(69)$ & $7(13)$ & $35(53)$ & $11(28.2)$ & $84(61.3)$ & $18(19.4)$ \\
\hline $\mathrm{No}$ & $22(31)$ & $47(87)$ & $31(47)$ & $28(71.8)$ & $53(38.7)$ & $75(80.6)$ \\
\hline Total & $71(100)$ & $54(100)$ & $66(100)$ & $39(100)$ & $137(100)$ & $93(100)$ \\
\hline
\end{tabular}

Source: Personal survey. * Figures in the bracket represent the percentage

Table: 2

Terms and condition of wage advancement against future commitment of labour

\begin{tabular}{|c|c|c|c|c|c|c|c|}
\hline & & \multicolumn{2}{|c|}{$\begin{array}{c}\text { Landless Labour } \\
\text { Households }\end{array}$} & \multicolumn{2}{|c|}{$\begin{array}{c}\text { Other than Landless } \\
\text { Households }\end{array}$} & \multicolumn{2}{|c|}{$\begin{array}{c}\text { All Agricultural } \\
\text { Labourers }\end{array}$} \\
\hline & & $\begin{array}{l}\text { All } \\
\text { Villages in } \\
\text { Nadia } \\
\end{array}$ & $\begin{array}{l}\text { All } \\
\text { Villages in } \\
\text { Jalpaiguri }\end{array}$ & $\begin{array}{l}\text { All } \\
\text { Villages in } \\
\text { Nadia } \\
\end{array}$ & $\begin{array}{l}\text { All } \\
\text { Villages in } \\
\text { Jalpaiguri }\end{array}$ & $\begin{array}{l}\text { All } \\
\text { Villages in } \\
\text { Nadia } \\
\end{array}$ & $\begin{array}{l}\text { All } \\
\text { Villages in } \\
\text { Jalpaiguri }\end{array}$ \\
\hline \multirow{3}{*}{$\begin{array}{l}\text { Does it involve } \\
\text { underpayment of } \\
\text { work }\end{array}$} & yes & $41(83.7)$ & $6(85.7)$ & $23(65.7)$ & $10(83.3)$ & $64(76.2)$ & $16(84.2)$ \\
\hline & no & $8(16.3)$ & $1(14.3)$ & $12(34.3)$ & $2(16.7)$ & $20(23.8)$ & $3(15.8)$ \\
\hline & total & $49(100)$ & $7(100)$ & $35(! 00)$ & $12(100)$ & $84(100)$ & $19(! 00)$ \\
\hline \multirow{3}{*}{$\begin{array}{l}\text { Does it working } \\
\text { on priority basis }\end{array}$} & yes & $45(91.8)$ & $7(100)$ & $25(71.4)$ & $12(100)$ & $70(83.3)$ & $19(100)$ \\
\hline & no & $4(8.2)$ & 0 & $10(28.6)$ & 0 & $14(16.7)$ & 0 \\
\hline & total & $49(100)$ & $7(100)$ & $35(100)$ & $12(100)$ & $84(100)$ & $19(100)$ \\
\hline \multirow{3}{*}{$\begin{array}{l}\text { Does it involve } \\
\text { normal work } \\
\text { condition? }\end{array}$} & yes & $13(26.5)$ & $1(14.3)$ & $10(28.6)$ & $5(41.7)$ & $24(28.6)$ & $6(31.6)$ \\
\hline & no & $36(73.5)$ & $6(85.7)$ & $25(71.4)$ & $7(58.3)$ & $60(71.4)$ & $13(68.4)$ \\
\hline & total & $49(100)$ & $7(100)$ & $35(100)$ & $12(100)$ & $84(100)$ & $19(100)$ \\
\hline
\end{tabular}

Source: Personal survey. * Figures in the bracket represent the percentage.

\section{APPENDIX -2}

Section A 
International Journal of Social Science and Economic Research

ISSN: $2455-8834$

Volume:06, Issue:07 "July 2021"

For examining the economic conditions of agricultural labourer's in West Bengal, we choose our field survey area in two districts, Nadia and Jalpaiguri based on agricultural performance. We have taken cropping intensity and net irrigated area as indicators of agricultural performance. The table below shows the cropping intensity and net area irrigated as a percentage of net sown area. Cropping intensity and area irrigated in Nadia is above the State's average, whereas for Jalpaiguri, both the indicators are below State average. Jalpaiguri is a rain-fed area whereas in Nadia irrigation comprises of shallow tube well (STW), deep tube well (DTW) and Canal irrigation.

\begin{tabular}{|l|l|l|l|}
\hline Districts & $\begin{array}{l}\text { Area irrigated as a } \\
\text { percentage of Nedping } \\
\text { Sown Area. }\end{array}$ & $\begin{array}{l}\text { Area under Hity(in } \\
\text { yercent) } \\
\text { pelding variety as a } \\
\text { percentage of Net Sown } \\
\text { Area }\end{array}$ \\
\hline Jalpaiguri & 26.9 & 158.38 & 1.99 \\
\hline Nadia & 87.5 & 217.19 & 49.49 \\
\hline West Bengal. & 55.4 & 170.61 & 25.88 \\
\hline
\end{tabular}

Source: Census of India. 2000

Boron Beria and Jalalkhali were the two developed villages from the advanced area (Nadia). Almost 54.5 percent of the cultivated area of Jalalkhali village and 87.5 percent of cultivated area of Boron Beria village receives irrigation.The main crops grown here are two varieties of rice (boro or summer rice and aman or winter rice) and Jute. Other crops include pluses, vegetables and banana cultivation. Multiple cropping does exist in these villages where rice is grown along with vegetables or pulses. The yield of rice in the advanced region (Nadia district) is anything between 63 and 90 (approx) tons per hectare whereas the yield of jute is at 37.5 tons (approx) per hectare. Mechanization of farms in these areas was widely visible where tractors, power tillers had replaced a large part of ploughing by bullock. Also powered/manual threshing machine was also seen. Private - moneylenders were active in the villages. Traders, who provide fertilizers and edible commodities also, provide goods to the marginal farmers and landless labourer's in lieu of future sale of crops or labour which ever the case maybe. Tendency of employing attached labour in on a decline among big and medium farmers. The dominant form of the rental contact for tenants is share rent (where one third of the produce has to be given to the owner) in kind.

Bahadur and Jugi Bhita are the two underdeveloped villages from the backward area (Jalpaiguri). Rain remains the principal source of irrigation in these areas. Though government has built Canals under the Teesta river project but only 15-20 percent of the gross cropped areas receive canal irrigation. The main crop grown here was mainly aman rice (winter rice), boro rice (summer rice) was grown only on 5-10 percent of the cultivated area. Other crops include potato 
cultivation. The yield of rice varied anything between 27 and 49.5 tons per hectare. Farm mechanization in these areas was almost absent, ploughing was done mostly by bullock and threshing was done in traditional way. Private -moneylenders were active in the villages, traders who provided fertilizers and edible commodities also provided goods to the marginal farmers and landless labourer's in lieu of future sale of crops or labour which ever the case maybe. Tendency of employing attached labour is on a decline among big and medium farmers. The dominant form of the rental contact for tenants was fixed rent in kind. This is the district where the national rural labour employment programme (NREGA) of 100 days employment is implemented. However, labourer's got anything between 5-20 days of work under rural labour employment programme. The yield of rice in the backward region (Jalpaiguri district) is anything between 27 and 49.5 tons per hectare. A total 271 households were selected for the survey.

\section{Section B}

Table 3, clearly shows that per capita monthly income of the households from all sources is higher at Rs. 322 and Rs. 348 in the villages (Boron Beria, Jalalkhali) of advanced district than in the villages of the backward (Bahadur and Dundee Bhita) district where per capita monthly expenditure was Rs. 309 and 291 respectively. Compared to the household's average per capita monthly expenditure, average per capita monthly income is low. This implies that most of the agricultural labour households are deficit households (table 4), where per capita monthly expenditure is higher than per capita monthly income. Proportion of deficit households is higher among landless labour households in all the villages (except Boron Beria in Nadia district) than agricultural labour households with land (owned or leased in). In Nadia district, 74.6 percent of landless households and 77.27 of other than landless households are deficit households. On the other hand, 70.13 percent other than landless households and 81.13 percent of landless households are deficit households in Jalapiguri district.

Table: 3

Average per Capita Monthly Income and Expenditure from All Sources

\begin{tabular}{|l|l|l|l|l|}
\hline & $\begin{array}{l}\text { Average number } \\
\text { of members in } \\
\text { the households }\end{array}$ & $\begin{array}{l}\text { Per capita } \\
\text { (monthly) income } \\
\text { from all sources }\end{array}$ & $\begin{array}{l}\text { Per capita } \\
\text { (monthly) } \\
\text { expenditure }\end{array}$ & $\begin{array}{l}\text { Per capita } \\
\text { Deficit (monthly) }\end{array}$ \\
\hline Boron Beria. & 4.9 & 322 & 365 & -43 \\
\hline Jalalkhali & 4.4 & 348 & 441 & -93 \\
\hline Bahadur. & 4.7 & 309 & 392 & -83 \\
\hline
\end{tabular}


International Journal of Social Science and Economic Research

ISSN: $2455-8834$

Volume:06, Issue:07 "July 2021"

\begin{tabular}{|l|l|l|l|l|} 
& & & \\
Dundee Bhita. & 5.6 & 291 & 347 & -56 \\
\hline
\end{tabular}

Source: Personal survey

Table: 4

Proportion of Deficit Households in the Surveyed Villages

\begin{tabular}{|l|l|l|l|l|}
\hline & \multicolumn{2}{|l|}{$\begin{array}{l}\text { All } \\
\text { Villages in Nadia }\end{array}$} & \multicolumn{2}{l|}{$\begin{array}{l}\text { All surveyed villages } \\
\text { in Jalpaiguri }\end{array}$} \\
\hline & $\begin{array}{l}\text { Land } \\
\text { less }\end{array}$ & $\begin{array}{l}\text { Other } \\
\text { than } \\
\text { landless }\end{array}$ & Landless & $\begin{array}{l}\text { Other } \\
\text { than } \\
\text { landless }\end{array}$ \\
\hline $\begin{array}{l}\text { Deficit } \\
\text { Household }\end{array}$ & 51 & 53 & 29 & 43 \\
\hline $\begin{array}{l}\text { Non-Deficit } \\
\text { Household }\end{array}$ & $(77.27)$ & $(74.6)$ & $(70.73)$ & $(81.13)$ \\
\hline & 66 & 18 & 12 & 10 \\
Total & $(100)$ & $(100)$ & $(100)$ & $(10.87)$ \\
\hline
\end{tabular}

Source: Personal survey. Note: Figures in the bracket represent percentage

The poverty line in West Bengal in rural areas was Rupees 382.82 per year (as on 2008). If we compare the average per capita monthly income of the agricultural labourer's in Nadia and Jalpaiguri with the poverty line in West Bengal, then in all the villages' average per capita monthly income falls short of the poverty line of Rupees 382.82 per year. 
International Journal of Social Science and Economic Research

ISSN: 2455-8834

Volume:06, Issue:07 "July 2021"

Table: 5

Proportion of the Sample Households Below and Above Poverty Line in Nadia

\begin{tabular}{|l|l|l|l|l|}
\hline Villages & & $\begin{array}{l}\text { Below } \\
\text { poverty } \\
\text { line }\end{array}$ & $\begin{array}{l}\text { Above } \\
\text { poverty } \\
\text { line. }\end{array}$ & Total \\
\hline Jalpaiguri & Number of households & $71(76.0)$ & $23(24.0)$ & $94(100)$ \\
\hline Nadia & Number of households & $100(73)$ & $37(27)$ & $137(100)$ \\
\hline
\end{tabular}

Source: Personal survey

Note: Figures in the bracket represent percentage.

In both the village of Nadia (as shown in table c) proportion of agricultural labourer's below poverty line is above 70 percent. In Jalpaiguri, this figure was 76 percent in both the villages (as shown in table 5). Agricultural labour households below poverty line had higher dependency ratio, lower earning member, had large families and lower per capita income.

\section{Appendix: 3 .}

Growth rates of employment and wages

Table: 6

\section{Growth of aggregate employment}

\begin{tabular}{|c|c|c|c|c|c|c|c|}
\hline & & \multicolumn{3}{|c|}{$\begin{array}{c}\text { Usual Principal + Subsidiary } \\
\text { Status (UPSS) }\end{array}$} & \multicolumn{2}{c|}{ Current Daily Status (CDS) } \\
\hline & & Male & Female & $\begin{array}{c}\text { Total } \\
\text { person }\end{array}$ & Male & Female & $\begin{array}{c}\text { Total } \\
\text { person }\end{array}$ \\
\hline All India & $1983-1993 / 94$ & 2.04 & 1.81 & 1.95 & 2.33 & 2.8 & 2.47 \\
\hline & $1993 / 94-2004 / 05$ & 1.44 & 1.58 & 1.48 & 1.31 & 1.53 & 1.35 \\
\hline $\begin{array}{c}\text { West } \\
\text { Bengal }\end{array}$ & $1983-1993 / 94$ & 2.36 & 1.98 & 2.26 & 3.00 & 4.20 & 3.10 \\
\hline & $1993 / 94-2004 / 05$ & 1.74 & 1.19 & 1.58 & 1.40 & 2.40 & 1.60 \\
\hline
\end{tabular}

Note: Growth rate implies compound annual growth rate.

Source: NSSO reports on Employment and Unemployment. Report on the Third Quinquennial Survey on Employment and Unemployment (1983): Survey Results -All India, Report No. 341; 
Employment and Unemployment in India, 1993-94, Fifth Quinquennial Survey, NSS 50 ${ }^{\text {th }}$ round, and Report No. 409. Employment and Unemployment in India, (1999-2000), Report No. 455. Employment and Unemployment in India, (1999-2000), Report No. 512. For 2004/05 unit level data of NSS ${ }^{16}$ have been used

Table : 7

Growth rates of average daily wage of men and women belonging to the agricultural labourer households in agricultural operations at 1999-00 prices

\begin{tabular}{|l|l|l|l|l|}
\hline & \multicolumn{2}{|l|}{ Male } & \multicolumn{2}{l|}{ Female } \\
\hline & $\begin{array}{l}1983- \\
1993 / 9 \\
4\end{array}$ & $\begin{array}{l}1993 / 94 \\
-\end{array}$ & $\begin{array}{l}1983- \\
1993 / \\
2004 / 05\end{array}$ & $\begin{array}{l}1993 / 94- \\
2004 / 05\end{array}$ \\
\hline $\begin{array}{l}\text { West } \\
\text { Bengal }\end{array}$ & 8.1 & 1.5 & 13.1 & 1.1 \\
\hline $\begin{array}{l}\text { All } \\
\text { India }\end{array}$ & 7.0 & 3.3 & 7.5 & 4.7 \\
\hline
\end{tabular}

Source: Rural Labour Enquiry: Report on Wages and earnings of

Rural Labour Households, 1983-1993-94 and 1999/00.

For 2004/05 unit level data of NSS have been used

Table: 8

Unemployment rates in West Bengal and India (rural)

\begin{tabular}{|l|l|l|l|l|}
\hline & \multicolumn{2}{|l|}{$\begin{array}{l}\text { Usual principal } \\
\text { +subsiadiary status) }\end{array}$} & \multicolumn{2}{l|}{ Current Daily Status. } \\
\hline West Bengal & RM & RF & RM & RF \\
\hline 1983 & 3.9 & 4.5 & 14.4 & 24.0 \\
\hline $1987 / 88$ & 3.0 & 10.6 & 4.6 & 15.2 \\
\hline $1993 / 94$ & 2.8 & 4.6 & 8.7 & 11.2 \\
\hline $1999 / 00$ & 3.4 & 3.8 & & \\
\hline $2004 / 05$ & 3.1 & 8.1 & 11.1 & 11.6 \\
\hline
\end{tabular}

16 Thanks to Dr. S. Sakhtivel for helping out with the extraction and tabulation of unit level data. 
International Journal of Social Science and Economic Research

ISSN: 2455-8834

Volume:06, Issue:07 "July 2021"

\begin{tabular}{|l|l|l|l|l|}
\hline All India & & & & \\
\hline 1983 & 2.1 & 1.4 & 7.5 & 9.0 \\
\hline $1987 / 88$ & 2.8 & 3.5 & 4.6 & 4.7 \\
\hline $1993 / 94$ & 2.0 & 1.4 & 5.6 & 5.6 \\
\hline $1999 / 00$ & 2.1 & 1.5 & 7.2 & 7.0 \\
\hline $2004 / 05$ & 2.1 & 3.1 & 8.0 & 8.7 \\
\hline
\end{tabular}

Source: NSSO reports on employment and unemployment. Report No. 341, 409, 455, 512

Note: The figures represent size of unemployment as percentage of labour force. RM= Rural

Male. $\mathrm{RF}=$ Rural Female.

\section{REFERENCES}

Bardhan, A. and P. Rudra, 1974a. Interlinkage of land, labour and credit relations, an analysis of village survey data in east India. Economic and Political Weekly, Annual Number February.

Bardhan, A. and P. Rudra, 1979b. Terms and condition of labour contracts in agriculture, results of a survey in West Bengal . Oxford Bulletin of Economics and Statistics, 43( 1).

Bardhan, A. and P. Rudra, 1980c. Labour, employment and wages, results of a survey in West Bengal. Economic and Political Weekly, 30 August issue.

Bharadwaj, K, 1974a. Productions conditions in Indian agriculture, a study based on farm management study. India: Cambridge University Press.

Bharadwaj, K, 1992b. Labour markets, employment policies and the dynamics of developmet. Daniel Thorner Memorial Lecture Series. Bangladesh Institure of Develpmet Studies, Dhaka.

Bhadhuri, A, 1983. The economic structure of backward agriculture. India: Macmillan India Ltd.

Bardhan, P,1983. Labour-tying in a poor agrarian economy, a theoretical and empirical analysis. The Quarterly Journal of Economics, 98(3).

Byres, T, J,1999. Rural labour relations in India, persistent themes, common process and differential outcome. Journal of Peasant Studies, 26(2).

Chattopadhay, M. and Bhattacharaya, 1984. Land, labour and credit relations in a peasant movement belt. Social Scientist, 12(3). 
Dreze, D. and A. Mukherjee, 1987a. Labour contracts in rural India, theories and evidences. Discussion Paper No. 7. Development Research Programme.

Dreze, D. and A. Mukherjee, 1986b. Rural labour markets in India, theories and evidences. IEA congress. New Delhi.

Dreze, J. et al., 1992. Economic mobility and agricultural labour in rural India, a case study. Development Economics Research Programme. London School of Economics.

Jha, P.K , 1997 . Agricultural Labourers in India. India: Vikas Publishing House.

Patnaik, U, 1987. Peasant class differentiation, a study in method with reference to Haryana. New Delhi: Oxford University Press.

Ramachandran, V.K, 1990. Wage freedom and unfreedom in agriculture, an Indian case study. India: Claredon Press.

Rudra, A, 1982. Extra Economic Constraints on Agricultural Labourers . ILO-ARTEP

Srivastava, R, 1989a. Interlinked modes of expliotation in Indian agriculture during transition , a case study. Journal of Peasant Studies, 16( 14) .

Srivastava, R, 1996b. Agrarian Change and Labour Process. In Peter Robb ed. Meanings of Agriculture. New Delhi: Oxford University Press.

Srivastava, R, 1999c. Rural labour in Uttar Pradesh, emerging features of subsistence, contradiction and resistance. Journal of Peasant Studies, 26(2).

Thorner, D. and A. Thorner, 1962. Land and labour in India. India : Asia Publishing House. 